\title{
Comparison of Serum and Salivary Alpha-Fetoprotein Levels in Pregnancies Complicated with Neural Tube Defects
}

\section{Nöral Tüp Defekti ile Komplike Gebeliklerde Serum ve Tükürük Alfa-fetoprotein Düzeylerinin Karşılaştırılması}

\author{
Talip Karacor ${ }^{1 \oplus}$, Mehmet Bulbul ${ }^{1 \oplus}$, Mehmet $\operatorname{Can}_{\operatorname{Nacar}^{1}}{ }^{\oplus}$, Pınar Kirici ${ }^{1 \oplus}$, Muhittin Onderci ${ }^{2} \oplus$ \\ Nurullah Peker ${ }^{3 \oplus}$, Sibel Sak ${ }^{4} \oplus$
}

${ }^{1}$ Adlyaman University Faculty of Medicine, Department of Obstetrics and Gynecology, Adiyaman, Turkey

${ }^{2}$ Adiyaman University Faculty of Medicine, Department of Biochemistry, Adiyaman, Turkey

${ }^{3}$ Dicle University Faculty of Medicine, Department of Obstetrics and Gynecology, Diyarbakır, Turkey

${ }^{4}$ Harran University Faculty of Medicine, Department of Obstetrics and Gynecology, Şanlıurfa, Turkey

Received: 29.04.2020 / Accepted: 17.07.2020 / Published Online: 30.09.2020

Cite as: Karacor T, Bulbul M, Nacar MC, Kirici P, Onderci M, Peker N, Sak S. Comparison of serum and salivary alpha-fetoprotein levels in pregnancies complicated with neural tube defects. Med J Bakirkoy 2020;16(3):212-7.

ABSTRACT

Objective: To compare the serum and salivary values of alpha-fetoprotein (AFP) used in screening neural tube defects (NTD) during pregnancy. To investigate whether saliva can be used instead of serum in NTD screening.

Method: The study was conducted between May 2018 - November 2019 at Adiyaman University. The study included 41 pregnant women complicated by NTD and 44 healthy pregnant women. Three $\mathrm{m} /$ venous blood and $2 \mathrm{~m} / \mathrm{saliva}$ samples were taken from both groups. Serum and saliva samples were not diluted. AFP concentration was measured at $450 \mathrm{~nm}$ by using commercially available enzyme-linked immunoassay. The intra-, and inter- test assay coefficients (CVs) of the kit were $<8 \%$ and $<10 \%$, respectively. SPSS 21 program was used for data analysis. Mann-Whitney Test was used for the analysis of continuously changing parameters. The correlation coefficient was calculated by Spearman test. A p value of less than 0.05 was accepted for statistical significance.

Results: When serum and salivary AFP values were compared between the two groups, the AFP values were found to be higher in both NTD group samples $(p<0.001, p<0.001)$. In both groups, correlation analysis for serum and salivary AFP values showed a strong positive correlation $(r=0.730, p<0.001)$. When the cut-off value for serum AFP is taken as 0.26, NTD can be determined with $100 \%$ sensitivity and $90 \%$ specificity (AUC: $0.932, p<0.001$ ). When the cut-off value for salivary AFP is taken as 0.034 , it can detect NTD with $95 \%$ sensitivity and $92 \%$ specificity (AUC: $1.00, p<0.001$ ).

Conclusion: Salivary and serum AFP values showed strong positive correlation between themselves. We believe that saliva can be used in NTD screening performed by AFP measurement.

Keywords: neural tube defect, alpha-fetoprotein, saliva, anomaly, screening test

öz

Amaç: Gebelikte nöral tüp defekti (NTD) taramasında kullanılan alfa-fetoproteinin (AFP) serum ve tükürük değerlerini karşılaştırmak. NTD taramasında serum yerine tükürük örneğinin kullanıp kullanılamayacağını araștırmak.

Yöntem: Çalışma Mayıs 2018 - Kasım 2019 tarihleri arasında Adıyaman Üniversitesi'nde yapıldı. Çalışmaya gebeliği NTD ile komplike olmuş 41 gebe ve sağlıklı gebeliği olan 44 gebe dâhil edildi. Her iki grup gebelerden $3 \mathrm{ml}$ venöz kan ve $2 \mathrm{ml}$ tükürük örneği alındı. Serum ve tükürük numuneleri seyreltilmedi. AFP konsantrasyonu, ticari olarak temin edilebilen enzim bağlı immünolojik test kullanılarak $450 \mathrm{~nm}$ 'de ölçüldü. Kitin intra- ve inter- test tahlil katsayısı (CV) sırasıyla $<\% 8$ ve <\% 10 idi. Verilerin analizi için SPSS 21 programı kullanıldı. Sürekli değişen parametrelerin analizi için Mann-Whitney Test kullanıldı. Korelasyon katsayısı Spearman testi ile hesaplandı. Istatistiksel anlamlılık için 0,05'den küçük $p$ değeri kabul edildi.

Bulgular: iki grup arasında serum ve tükürük AFP değerleri karșılaștırıldığında, AFP değeri her iki örnekte de NTD grubunda istatistiki olarak daha yüksek saptandı $(p<0,001, p<0,001)$. Her iki grupta Serum ve tükürük AFP değerleri için yapılan korelasyon analizinde pozitif yönde güçlü korelasyon elde edildi $(r=0,730, p<0,001)$. Serum AFP için cut-off değer 0,26 alındığında $\% 100$ sensitivite ve $\% 90$ spesifisite ile NTD belirlenebilir (AUC: 0,932, p<0,001). Tükürük AFP için cut-off değeri 0,034 alındığında, \%95 sensitivite ve \%92 spesifisite ile NTD'ni belirleyebilir (AUC: $1,00, p<0,001)$.

Sonuç: Tükürük ve serum AFP değerleri güçlü pozitif korelasyon göstermiştir. AFP ölçümü ile yapılan NTD taramasında tükürüğün kullanılabileceği kanaatindeyiz.

Anahtar kelimeler: NTD taramasında tükürük AFP düzeyleri

\section{Corresponding Author:}

talipkaracor@gmail.com
T. Karacor 0000-0003-1349-1569

M. Bulbul 0000-0001-5695-2586

M. C. Nacar 0000-0001-5463-4197

P. Kirici 0000-0001-7616-4181
M. Onderci 0000-0002-8100-0242

N. Peker 0000-0002-3285-9990

S. Sak 0000-0001-7401-3945

(C) Telif hakkı Sağlık Bilimleri Üniversitesi Bakırköy Dr. Sadi Konuk Eğitim ve Araştırma Hastanesi'ne aittir. Logos Tıp Yayıncılık tarafından yayınlanmaktadır. Bu dergide yayınlanan bütün makaleler Creative Commons Atff-GayriTicari 4.0 Uluslararası Lisansı ile lisanslanmıştır.

(c) Copyright Health Sciences University Bakırköy Sadi Konuk Training and Research Hospital. This journal published by Logos Medical Publishing.

Licenced by Creative Commons Attribution-NonCommercial 4.0 International (CC BY) 


\section{INTRODUCTION}

Neural tube defect (NTD) is the closure defect that occurs during the early embryonic development of the central nervous system. The defect can occur anywhere in the cranium and the medulla spinalis. Its incidence varies geographically over a wide range of $0.2-3 \%{ }^{(1)}$. These common serious anomalies are the leading cause of death and serious disability in the neonatal period ${ }^{(2)}$. For this reason, all pregnant women are subjected to screening program for NTD in the early stages of pregnancy. Biomarkers and imaging methods are used in screening programs. The most commonly used biomarker for NTD is alpha-fetoprotein (AFP) ${ }^{(3)}$. AFP is a plasma protein produced in yolk sac and fetal liver during pregnancy. AFP passes into amniotic fluid and maternal blood at high concentrations ${ }^{(4)}$. It starts to increase in the first week of pregnancy and reaches the peak level in the first trimester. Then it decreases a little and remains at this level until the $32^{\text {nd }}$ week. It is removed from the blood in a short time after birth. AFP also increases in other pregnancy pathologies such as omphalocele, gastroschisis, and yolk sac tumor ${ }^{(5)}$. It also increases in hepatocellular cancer (HCC), hepatoblastoma and germ cell tumors during adulthood (6). The measurement of AFP is done by ELISA methods and serum is usually used for measurement (7). Today, medicine is shifting to noninvasive diagnostic and treatment methods day by day. Therefore, especially noninvasive screening tests will increase applicability and patient compliance. In addition to serum, screening tests are also performed on urine and saliva samples where sampling is more painless and noninvasive ${ }^{(8)}$.

While urine is used frequently in these screening tests, saliva is used very rarely. However, saliva is the easiest way for ease of sampling ${ }^{(9)}$.

In our study, we wanted to investigate whether AFP, which is detected in high levels in serum in second trimester pregnants complicated with NTD, can also be detected in saliva samples. Therefore, we aimed to compare the AFP levels in the serum and saliva samples of second trimester healthy pregnants and second trimester pregnants whose pregnancy was complicated by NTD.

\section{MATERIAL and METHOD}

\section{Study design}

This randomized prospective study was conducted at the Adıyaman University Obstetrics and Gynecology Clinic between May 2018 and November 2019. Before starting the study, we got approval from Adıyaman University local ethics committee on 05.22.2018 with registration number 2018/4-19. NTD screening is performed in all pregnant women between the $12^{\text {th }}$ and $20^{\text {th }}$ gestational weeks in our clinic. Ultrasonographic (US) examination and measurement of maternal AFP serum values were used in NTD screening. We selected pregnant women in the NTD group included in our study randomly from pregnant women who were diagnosed with NTD in our outpatient clinic or diagnosed with NTD at the maternity clinic and referred to our outpatient clinic. A total of 41 pregnant women whose pregnancy was complicated by NTD were included in the study. Pregnancies with fetal anomalies other than NTD, multiple pregnancies and pregnant women who were reluctant to participate were excluded from the study. In addition, pregnant women with chronic diseases such as diabetes mellitus, hypertension, hepatitis and those using medications regularly were also excluded.

As a control group, 44 randomly selected pregnant women in the same gestational week with the study group of patients admitted to the obstetric outpatient clinic for routine control were compared with the study group. Pregnant women with any fetal anomaly, multiple pregnancies, pregnant women with chronic disease and using medications regularly were not included in the control group of pregnant women. Cases in the NTD and control groups were informed about the study. Written consent was obtained from all pregnant women who volunteered to participate in the study.

\section{Collection of samples}

Approximately $3 \mathrm{ml}$ of venous blood samples were pipetted into the anticoagulant tubes after info obtaining informed consent of the NTD and control group of pregnant women. The samples were centrifuged at $3500 \mathrm{rpm} / \mathrm{min}$ for 10 minutes without waiting. Separated plasma portions were placed in the Eppendorf tubes with automatic pipettes and stored 
at -80 degrees until the day of analysis. About $2 \mathrm{ml}$ of saliva samples were taken from the same patients and pipetted into the Eppendorf tubes without any treatment and stored at -80 degrees Celsius until the day of study. Patients were advised not to eat anything for at least 4-6 hours before giving a saliva sample.

\section{Measurements}

The alpha-fetoprotein concentration in serum and saliva samples was measured at $450 \mathrm{~nm}$ using a commercially available enzyme-bound immunoassay (Catalog no: EH0359, Wuhan Fine Biological Technologies Co. Ltd. China). The test was carried out as directed by the manufacturer. Samples were not diluted. The intra-, and inter- test assay coefficients (CVs) of the kit were $<8 \%$ and $<10 \%$, respectively.

\section{Statistics}

SPSS 21 (IBM Statistical Package for Social Sciences Statistics version 21.0, Chicago, USA) program was used for data analysis. The demographic data, serum and saliva AFP values of the patients were compared between the groups with the Mann-Whitney Test. Correlation coefficient was calculated with Spearman

Table 1. Demographic characteristics of pregnant women in both groups.

\begin{tabular}{lccc}
\hline & $\begin{array}{c}\text { NTD Group } \\
\mathbf{n}=\mathbf{4 1}\end{array}$ & $\begin{array}{c}\text { Control Group } \\
\mathbf{n}=\mathbf{4 4}\end{array}$ & $\mathbf{p}$ \\
\hline Age (year) (mean \pm SD) & $26,6 \pm 3,3$ & $27,8 \pm 4,4$ & 0,176 \\
BMI (kg/m²) (mean \pm SD) & $21,8 \pm 2,1$ & $21,5 \pm 2,0$ & 0,525 \\
Gw (hafta) (mean \pm SD) & $15,8 \pm 0,9$ & $15,3 \pm 1,6$ & 0,126 \\
G (mean $\pm S D)$ & $2,7 \pm 1,2$ & $3,2 \pm 1,4$ & 0,092 \\
A (mean $\pm S D)$ & $1,6 \pm 1,1$ & $1,9 \pm 1,1$ & 0,258 \\
\hline
\end{tabular}

BMI: Body mass index, Gw: Gestational week, G: Gravidity,

A: Alive SD: Standart Deviasyon

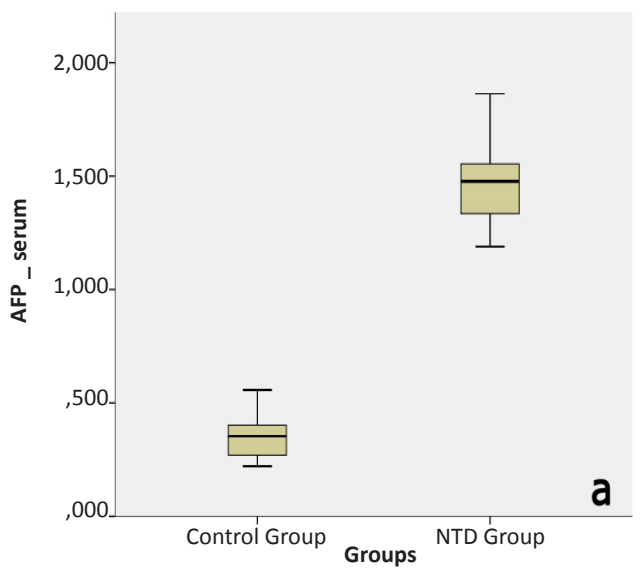

test. Data were presented as mean $\pm S D$. $P$ value less than 0.05 was accepted for statistical significance. ROC analysis was performed on serum and saliva AFP values to determine the cut-off value that predicts NTD for AFP.

\section{RESULTS}

All pregnant women were between $12 \mathrm{w}+0 \mathrm{~d}$ and 20 $w+0 d$. There was no statistical difference between the two groups in terms of demographic data such as age, gravida, parity and BMI. Gestational weeks and demographic data of the pregnant women constituting the two groups are summarized in Table 1.

When comparing AFP values between the two groups, mean serum AFP level was statistically higher in NTD group $(1.393 \pm 0.310$ vs $0.357 \pm 0.097 \mathrm{ng} / \mathrm{mL}$, $\mathrm{p}<0.001)$. Again, when the saliva AFP values were compared between the two groups, the AFP values were found statistically higher in the NTD group $(0.518 \pm 0.259$ vs $0.106 \pm 0.054 \mathrm{ng} / \mathrm{mL}, \quad p<0.001)$ (Figure 1). The AFP values of both groups are summarized in Table 2.

Table 2. Serum and saliva AFP levels of pregnant women in both groups.

\begin{tabular}{lccc}
\hline & $\begin{array}{c}\text { NTD Group } \\
\mathbf{n}=\mathbf{4 1}\end{array}$ & $\begin{array}{c}\text { Control Group } \\
\mathbf{n}=\mathbf{4 4}\end{array}$ & $\mathbf{p}$ \\
\hline $\begin{array}{l}\text { AFP serum }(\mathrm{ng} / \mathrm{mL}) \\
\text { (mean } \pm \text { SD) }\end{array}$ & $1,393 \pm 0,310$ & $0,357 \pm 0,097$ & $<0,001^{*}$ \\
$\begin{array}{l}\text { AFP saliva }(\mathrm{ng} / \mathrm{mL}) \\
\text { (mean } \pm \text { SD) }\end{array}$ & $0,518 \pm 0,259$ & $0,106 \pm 0,054$ & $<0,001^{*}$ \\
\hline
\end{tabular}

NTD: Neural tube defect, AFP: Alpha-fetoprotein, SD: Standard Deviation

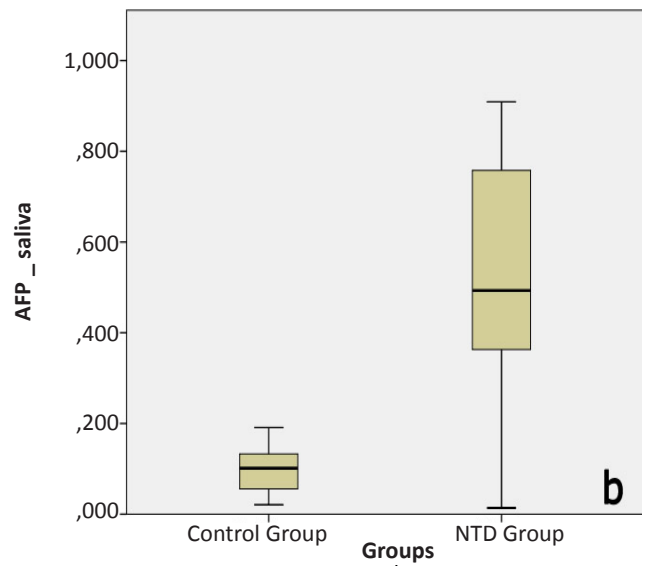

Figure 1. Average of serum (a) and saliva (b) AFP in both groups. AFP: Alfa-fetoprotein 


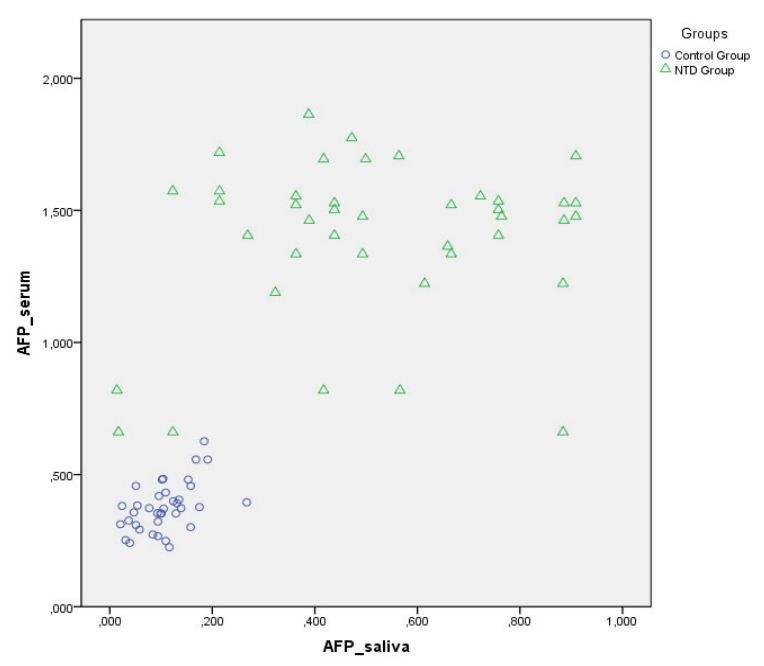

Figure 2. AFP correlation relationship between serum and saliva in both groups $(r=0,730, p<0,001)$.

AFP: Alfa-fetoprotein

In the correlation analysis for serum and saliva AFP values in both groups, a positive correlation was detected $(r=0.730, p<0.001)$ (Figure 2).

When cut-off value of 0.26 is taken for serum AFP, NTD can be determined with $100 \%$ sensitivity, $90 \%$ specificity (AUC: 0.932, p<0.001). When cut-off value of 0.034 is taken for saliva AFP, it can determine NTD with 95\% sensitivity, 92\% specificity (AUC: 1.00, $\mathrm{p}<0.001$ ) (Figure 3).

\section{DISCUSSION}

A fetal anomaly such as NTD, akrania, or a defect at the level of the medulla spinalis may cause the baby to experience serious disabilities throughout its life (10). For this reason, it is an appropriate approach to screen all pregnant women without discrimination. AFP measurements, and obstetric ultrasonography are used as screening methods all over the world (3). Of these screening methods, USG should be performed by a gynecologist with a good obstetric experience or by a radiologist with an obstetric evaluation experience ${ }^{(11)}$. In this respect, it is difficult to use USG as a screening test, but high AFP detection in saliva or blood must be confirmed with USG. Screening tests should be a method in which all pregnant women can benefit equally in terms of cost-effectiveness, ease of application and accessibility. The measurement of AFP is quite practical compared to the ultrasonographic method in terms of applicability as a screening test ${ }^{(12)}$.

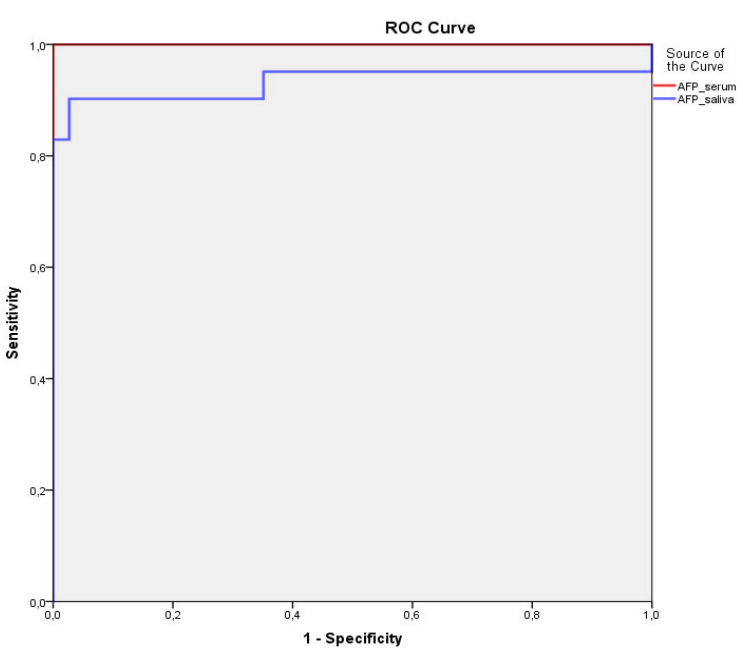

Figure 3. ROC analysis of serum and saliva AFP values in both groups (AUC: 0,932, $p<0,001$ ), (AUC: 1,00, $p<0,001$ ).

AUC: Area Under Curve, ROC: Receiver Operating Characteristic.

AFP measurement is usually done from serum. Venous blood collection is a procedure that hurts the patient. Although it is considered noninvasive, an attempt is made to the patient's body integrity. But taking the saliva sample is quite practical. In addition, contrary to what is required when taking venous blood samples, local antiseptic, syringe, laboratory tube and most importantly, qualified medical personnel are not needed. It can even be taken at home. For this reason, investigating the presence and density of AFP in saliva will increase the ease of application of the screening test. In the literature, saliva has been used in many studies to screen biomarkers ${ }^{(13,14)}$. These studies mostly included oral and head and neck tumors ${ }^{(15)}$. In our study, pregnancies complicated by NTD were evaluated. In addition, there are very few studies in the literature investigating AFP in saliva ${ }^{(16)}$. In our study, serum AFP values were significantly higher in NTD group compared to the control group, as expected. In addition, in the NTD Group, the AFP value in saliva was statistically higher than the control group $(p<0.001)$. When we looked at whether there was a correlation between serum and saliva AFP values, a strongly positive correlation was detected between the samples in both groups $(r=0.730, p<0.001)$. In our study, the detection of a biomarker in saliva, which is not related to the mouth and salivary gland, indicates that plasma proteins and other molecules pass from plasma into saliva. The passage of these proteins and molecules occurs by passive or active diffusion ${ }^{(13)}$. 
In studies with a very small sample size in the literature, the presence of AFP in saliva was evaluated in fibrotic diseases of the liver such as HCC and cirrhosis ${ }^{(16,17)}$. You et al. compared HCC cases and control group in their study, and the serum and saliva AFP values of patients with $\mathrm{HCC}$ were statistically higher than values of the control group patients. In their study, a positive correlation was found between saliva and serum AFP levels in patients with HCC, as in our study ${ }^{(16)}$. As a result of studies with HCC, currently AFP is used in the follow-up of diagnosis and treatment of the patients, and provides strong relevant evidence. In this study, it has been reported that $1-10 \%$ of serum AFP enter into saliva ${ }^{(16)}$. In our current study, this rate was $35.1 \%$ on average. In our study, we attributed the higher rate of transition of AFP into saliva to higher AFP levels in NTD complicated pregnancies when compared to HCC and other GIS malignancies (18). Because the density of the substances in passive or active diffusion is an important determinant on the extent of transition ${ }^{(19)}$. In addition, increased variations in hormonal balance and volume during pregnancy lead to relaxation in vascular smooth muscles and consequently enhance permeability. The escape of intravascular fluid into the interstitial space also increases during pregnancy ${ }^{(20)}$. These physiological changes in pregnancy helped to explain the higher rate of transition of AFP into saliva in pregnant women complicated with NTD. There are proportional differences in the transition of biomarkers in serum into saliva. The density of these biomarkers in saliva is less than that in serum. Therefore, evaluation of biomarkers in saliva with more sensitive analytical methods will help to obtain clearer data.

As a result, saliva is one of the easiest samples to store and process. Because of these advantages, using the saliva sample in the laboratory will provide convenience and advantages in many aspects. In our current study, we found that AFP measurements in screening tests for NTD can be performed in saliva samples instead of serum. We think that NTD screening test during pregnancy can be performed with saliva samples in more comprehensive studies on this subject to be performed in the future.

Ethics Committee Approval: Approval was obtained from Adıyaman University Non-Invasive Clinical
Research Ethics Committee (22.5.2018, 2018/4-19).

Conflict of Interest: Authors have not declared any potential conflict of interest and financial support.

Funding: None

Informed Consent: Informed consent was taken from all the participants.

\section{REFERENCES}

1. Greene ND, Copp AJ. Neural tube defects. Annu Rev Neurosci. 2014;37:221-42.

https://doi.org/10.1146/annurev-neuro-062012-170354

2. Desai VR, Gadgil N, Saad S, Raskin JS, Lam SK. Measures of health-related quality of life outcomes in pediatric neurosurgery: literature review. World Neurosurg. 2019;122:252-65.

https://doi.org/10.1016/j.wneu.2018.10.194

3. Cameron M, Moran P. Prenatal screening and diagnosis of neural tube defects. Prenat Diagn. 2009;29:402-11. https://doi.org/10.1002/pd.2250

4. Brock DJH, Sutcliffe RG. Early prenatal diagnosis of anencephaly. Lancet. 1972;9:1252-3. https://doi.org/10.1016/S0140-6736(72)92306-9

5. Seller MJ, Coltart TM, Campbell S, Singer JD. Early termination of anencephalic pregnancy after detection by raised alpha-fetoprotein levels. Lancet. 1973;14:73. https://doi.org/10.1016/S0140-6736(73)93264-9

6. Mehta N, Dodge JL, Roberts JP, Hirose R, Yao FY. Alphafetoprotein decrease from $>1,000$ to $<500 \mathrm{ng} / \mathrm{ml}$ in patients with hepatocellular carcinoma leads to Improved posttransplant outcomes. Hepatology. 2019;69:1193-205. https://doi.org/10.1002/hep.30413

7. Mancal P, Srámek M, Malbohan I, Simek L. The first clinical trial for determination of alpha 1 fetoprotein by means of Sevatest-ELISA AFP Kit (micro I). J Hyg Epidemiol Microbiol Immunol. 1988;32(2):209-17. PMID: 2457612.

8. Zhan Z, Guan Y, Mew K, Zeng W, Peng M, Hu P, et al. Urine alpha-fetoprotein and orosomucoid 1 as biomarkers of hepatitis B virus-associated hepatocellular carcinoma. Am J Physiol Gastrointest Liver Physiol. 2020;318:305-12. https://doi.org/10.1152/ajpgi.00267.2019

9. Kaczor-Urbanowicz KE, Carreras-Presas CM, Aro K, Tu M, Garcia-Godoy F, Wong DT. Saliva diagnostics current views and directions. Exp Biol Med. 2016;242:459-72. https://doi.org/10.1177/1535370216681550

10. Szabó N, Gergev G, Valek A, Eller J, Kaizer L, Sztriha L. Birth prevalence of neural tube defects: a populationbased study in South-Eastern Hungary. Childs Nerv Syst. 2013;29:621-7. https://doi.org/10.1007/s00381-012-1951-1

11. Robinson AJ, Blaser S, Toi A, Chitayat D, Halliday W, Pantazi S, et al. The fetal cerebellar vermis: assessment for abnormal development by ultrasonography and magnetic resonance imaging. Ultrasound $Q$. 2007;23:211-23

https://doi.org/10.1097/RUQ.0b013e31814b162c

12. Fuchs KM, Peipert JF. First trimester down syndrome screening: public health implications. Semin Perinatol. 
2005;29:267-71.

https://doi.org/10.1053/j.semperi.2005.05.003

13. Xiao H, Wong DT. Proteomics and its applications for biomarker discovery in Human Saliva. Bioinformation. 2011;5:294-6.

https://doi.org/10.6026/97320630005294

14. Nagler R, Bahar G, Shpitzer T, Feinmesser R. Concomitant analysis of salivary tumour markers-a new diagnostic tool for oral cancer. Clin Cancer Res. 2006;12:3979-84.

https://doi.org/10.1158/1078-0432.CCR-05-2412

15. Recker EN, Brogden KA, Avila-Ortiz G, Fischer CL, Pagan-Rivera K. Novel biomarkers of periodontitis and/ or obesity in saliva-An exploratory analysis. Arch Oral Biol. 2015;60:1503-9. https://doi.org/10.1016/j.archoralbio.2015.07.006

16. You XY, Jiang J, Yin FZ. Preliminary observation on human saliva alpha-fetoprotein in patients with hepatocellular carcinoma. Chin Med J (Engl).
1993;106(3):179-82. PMID: 7686840.

17. Chandra RK. Indian childhood cirrhosis: genealogic data, alpha-foetoprotein, hepatitis antigen and circulating immune complexes. Trans R Soc Trop Med Hyg. 1976;70:296-301.

https://doi.org/10.1016/0035-9203(76)90079-1

18. Johnson PJ. The role of serum alpha-fetoprotein estimation in the diagnosis and management of hepatocellular carcinoma. Clin Liver Dis. 2001;5:14559. https://doi.org/10.1016/S1089-3261(05)70158-6

19. Aps JK, Martens LC. Review: The physiology of saliva and transfer of drugs into saliva. Forensic Sci Int. 2005;150(2-3):119-31. https://doi.org/10.1016/j.forsciint.2004.10.026

20. Sizlan A, Kurt E. Physiological changes in pregnancy. Turkiye Klinikleri J Surg Med Sci. 2007;3(32):1-7. Available from: http://www.turkiyeklinikleri.com/ article/en-gebelik-fizyolojisi-48093.html 